\title{
PENERAPAN PROSES KEPERAWATAN DENGAN CARA BERPIKIR KRITIS
}

\author{
ANGEL OKTAVIA PURBA / 181101099 \\ angeloktavia013@gmail.com
}

\begin{abstract}
ABSTRAK
Proses keperawatan adalah suatu metode yang sistematis dan terorganisasi dalam pemberian asuhan keperawatan, yang difokuskan pada reaksi dan respond untuk individu suatu kelompok atau perorangan terhadap gangguan kesehatan yang dialami, baik actual maupun potensial. Menurut Yura Walsh ( 1978), proses keperawatan itu adalah Langkah-langkah sistematis untuk menentukan dan merencanakan penyelesaian masalah klien lalu mengimflementasikan dan mengevaluasi apakah rencana yang cukup efektif dalam menyelesaiakan masalah yang terjadi. Proses keperawatan juga mempunyai sifat-sifat yaitu dinamis, siklikal, interdependen, dan fleksibel.Pada proses keperawatan ada lima tahapan yaitu: pengkajian, diagnosis, perencnaan, implementasi dan evaluasi. Setiap tahap dari proses keperawatan saling terkait dan ketergantungan satu sama lain. Perawat harus mampu melaksanakan proses keperawatan dengan baik dan benar karena mutu pelayanan keperawatan itu sendiri ditentukan oleh perawat yang kompeten dalam bidangnya sehingga kualitas praktik keperawatan dapat ditingkatkan dan Dalam proses keperawatan mengandung banyak elemen berpikir kritis yang memungkinkan perawat membuat penilaian dan melakukantindakan berdasarkan nalar.
\end{abstract}

Kata Kunci : Pengertian proses keperawatan, tujuan dan manfaat proses keperawatan, asuhan keperawatan, fungsi dan sifat proses keperawatan,tahapan dalam proses keperawatan dan berpikir kritis dalam proses keperawatan

\section{LATAR BELAKANG}

Perawat merupakan suatu profesi yang memberikan pelayanan kesehatan kepada klien sesuai dengan standart yang berlaku.Perawat sebagai suatu profesi merupakan bagian dari tim kesehatan yang bertanggungjawab membantu klien sebagai individu, keluarga, dan masyarakat baik dalam kondisi sehat maupun sakit. Seiring perkembangan keperawatan, keilmuan dalam praktik Keperawatan pun turut berkembang. Berbagai penelitian berdasarkan fenomena yang ada di dunia pelayanan keperawata dilakukan.Asuhan keperawatan merupakan tulang punggung pelayanan yang terintegrasi dalam pelayanan kesehatan. Dalam pemberian asuhan keperawatan yang ditujuakan untuk pemenuhan kebutuhaan dasar klien guna tercapainya dan dipertahankannya kondisi sehat yang optimal. Untuk mencapai tujuan itu, dibutuhkan suatu pendekatan dengan metode ilmiah yang sistimatis sehingga dapat memecahkan masalah klien dalam keperawatan. 
Metode tersebut dinamakan proses keperawatan dimana proses keperawatan inidigunakan untuk membantu perawat melaukan praktik keperawatan secara sistematis dalam pecah masalah keperawatan. Dengan menggunakan metode ini perawat bisa mendemonstrasikan tanggungjawab kepada klien. Proses keperawatan juga memberikan sejauh apa yang dibutuhkan dalam asuhan keperawatan pada klien, keluarga dan komunitas dan juga merupakan metode yang efisien dalam membuat keputusan juga dalam pemecahan masalah baik actual, maupun potensi dalam mempertahankan kesehatan. Perawat harus mampu melaksanakan proses keperawatan dengan baik dan benar karena mutu pelayanan keperawatan itu sendiri ditentukan oleh perawat yang kompeten dalam bidangnya sehingga kualitas praktik keperawatan dapat ditingkatkan.

\section{TUJUAN}

Tujuan dari penulisan ini yaitu untuk mengetahui sejarah proses keperawatan, apa pengertian proses keperawatan, tujuan dan manfaat proses keperawatan, apa pengertian asuhan keperawatan, fungsi proses keperawatan, bagaimana sifat proses keperawatan dan bagaimana llangkah-langkah proses keperawatan.

\section{METODE}

Metode penulisan ini adalah Riterature Riview, dimana ini menganalisis artikel yang relevan dan berfokus pada tema Proses Keperawatan. Adapun artikel yang digunakan dalam literature ini menggunakan sumber dari buku teks, jurnal dengan memasukan kata kunci "Proses keperawatan" dimana jurnal yang di yang digunakan merupakan jurnal yang diiterbitkan pada 10 tahun terakhir.

\section{HASIL}

Berdasarkan pencarian literature didapatkan apa bagaimana kondep dasar proses keperawatan, sejaraha proses keperawatan, apa itu pengertian proses keperawatan, tujuan dan manfaat proses keperawatan, pengertian asuhan keperawatan, fungsi proses keperawatan, bagaimana sifat proses keperawatan dan apa saja langkahlangkah proses keperawatan. 


\section{PEMBAHASAN}

Seiring dengan

perkembangan

keperawatan, keilmuan dalam praktik keperawatan pun turut berkembang. Berbagai penelitian berdasarkan fenomenal yang ada di dunia pelayanan keperawatan dilakukan. Sebelum proses keperawatan ditemukan, perawat hanya meaksanakan tugas dan pekerjaan bberdasarkan instruksi dari dokter. Hal itu seolah menunjukkan bahwa keperawatan bukanlah suatu profesi yang mandiri dan berdasarkan ilmu. Padahal hal itulah yang yang merupakan ciri penting suatu profesi. Tugas yang dibebankan pada perawat dilakukan sebagai rutinitas sehingga ada yang hanya mengerjakan satu prosedur yang sama selama bertahun-tahun. Seiring perkembangan keperawatan , berbagai penemuaan dalam dunia keperawatan pun diperkenalkan, salah satunya adalah proses keperawatan. Pada tahun 1955, seorang ahli keperawatan bernama Hall memperkenalkan istilah proses keperawatan. Namun hal ini hanya sekedar istilah dan belum dilaksanakan. Kemudian delapan tahun kemudian, Wiedenbach memperkenalkan 3 langkah dalam proses keperawatan yaitu observasi, bantuan pertolongan dan vaalidasi. Kemudian perkembangan proses keperawatan berlanjut pada tahun 1967, dimasa Knowles menemukan istilah yang menjelaskan tentang discovery (penemuan), divide(membagi),decide( memutuskan), do (melakukkan), dan discrimination (membedaakan).

Perkembangaan proses keperawatan terus terjadi di tahun yang sama, fakultas keperawatan universitas khatolik Amerika memperkenalkan 4 tahap proses keperawatan yaitu, pengkajian, perencanaan, interventasi, dan evaluasi. Kemudian pada tahun 1982, national council of state boards of nursing menyempurnakan tahapan dari proses keperawatan menjadi 5 tahap yaitu,pengkajian,diagnosis,perencanaan, implementasi dan evaluasi. Lima tahap inilah yang sampai saat ini digunakan sebagai langkah-langkah proses keperawatan. Proses keperawatan itu sendiri adalah suatu metode yang sistematis dan terorganisasi dalam pemberian asuhan keperawatan, yang difokuskan pada reaksi dan respond untuk individu suatu kelompok atau perorangan terhadap gangguan kesehatan yang dialami, baik actual maupun potensial. Menurut Yura Walsh ( 1978), proses keperawatan itu adalah 
Langkah-langkah sistematis untuk menentukan dan merencanakan penyelesaian masalah klien lalu mengimflementasikan dan mengevaluasi apakah rencana yang cukup efektif dalam menyelesaiakan masalah yang terjadi. Sedangkan menutur Gordon (1997) proses keperawatan itu adalah suatu metode yang digunakan untuk mengidentifikasi dan memecahkan masalah. Secara umum tujuan proses keperawatan adalah untuk membuat kerangka konsep berrdasarkan kebutuhan individu dank lien, keluarga dan masyarakat (Carpenito dan Moyet 2007).Pelaksanaan proses keperwatan akan membuat seseorang perawat dapat menyelesaikan suatu masalah dengan penfdekatan yang ilmiah, sistematis dan logis sehingga menghasilkann pelayanan yang berkualitas kepada individu, keluarga dan masyarakat. Adapun manfaat dari proses berpikitr kritis adalah sebagai berikut bagi perawat manfaat yang di dapatkan yaitu: Perawat melakukan pendidikan keperawatan yang konsitens dan sistematis, meningkatkan kepuasan kerja dan rasa percaya diri, menimbulkan sikap professional, mencegah terjadinya malpraktik dan tindakan illegal, serta bertanggung jawab dan bertanggunggugat. Sementara itu, manfaat yang di dapatkkan klien dari pemberian asuhan keperawatan dengan pendekatan proses keperawatan yaitu: klien mendapatkan asuhan keperawatan yang berkualitas dan sesuai dengan standart, mendapatkan asuhan keperawatan yang berkesinambungan, mendapatkan asuhan keperawatan efektif dan efisien dengan partisipasi aktif dari klien. Dalam proses keperawatan asuhan keperawaan atau askep adalah proses atau tahapan kegiatan dalam perawatan yang diberikan langsung kepada pasien dalam berbagai tatanan pelayanan kesehatan. Pelaksanaan askep dilakukan beerasarkan kaidah-kaidah keperawatan sebagi suatu profesi yang didasarkan pada ilmu dan kita perawat yang bersifat humanistic dan berdasarkan kebutuhan objectif pasien untuk mengatasi maslaha yang dihadapi klien serta dilandasi kode etik dan etika keperawatan dalam lingkup wewenang serta tanggung jawab keperawatan.

Adapun fungsi dari proses keparawatan meliputi: 1. Membantu individu agar tidak bergantung pada orang lain 2.Mengajak individu untuk bisa berpartisipasi dalam bidaang kesehatan 
3.Membantu individu untuk memperoleh derajat kesehatan yang optimal.

4.Membantu individu untuk mengembangkan potensi dalam memelihara kesehatan secara teratur.

Proses keperawatan juga mempunyai sifat-sifat yaitu dinamis, siklikal, interdependen, dan fleksibel.Pada proses keperawatan ada lima tahapan yaitu: pengkajian, diagnosis, perencnaan, implementasi dan evaluasi. Setiap tahap dari proses keperawatan saling terkait dan ketergantungan satu sama lain. Kegiatan-kegiatan yang diakukan pada setiapa tahap dari proses keperawatan pada tahap pengkajian adalah mengumpulkan data seperti riwayat keperawatan, pemeriksaan fisik, dan pemeriksaan data sekunder lainnya ( catatan, hasil pemerksaan diagnostic dan literature). Setelah didapatkan maka tahap selanjutnya adalah diagnosis, pada tahap ini kegiatana yang dilakukan adalah memvalidasi data, mengoreksi dan mengelompokkan data, menginterpretasi data, mengidentfikasi masalah dari kelompok data, dan merumuskan diagnosis keperawatan. Selanjutnya adalah tahap perencanaan kegiatan yang dilakukan pda tahap ini adalah menyususn prioritas masalah, merumuskan tujuan dan kriteria hasil, memilih strategi asuhan keperawatan, melakukan konsultasi dengan tenaga kesehatan lainnya, dan menuliskan atau mendokumentasikan rencana asuhan keperawatan.

Selanjutnya pada tahap implementasi yaitu melakukan rencana yang telah dibuat pada klien. Adapun kegiata yang dilakuan pada tahap implementasi meliputi : pengkajian ulang, memperbaharui data dasar, meninjau dan merevisi rencana asuhan keperawatan yang telah dibua, dan melaksanakan intervesi keperawatan yang telah direncanakan.

Tahap akhir dari proses keperawatan yaitu tahap evaluasi. Pada tahap ini, kegiatan yang dilakukan adalah mengkaji respond klien setelah dilakukan intervensi keperawatan, membandingkan respond klien dengan kriteria hasil, memodifikasi asuhan keperawatan sesuai dengan hasil evaluasi, dan mengkaji ulang asuhaan keperawatan yang telah diberikan.

Untuk dapat mengaaplikasikan asuhan keperawatan, perawat harus memiliki keterampilan interpersonal yaitu keterampilan atau kemampuan dalam melakukan komunikasi, baik dengan 
klien maupun tim kesehatan lainnya. Kemudian keterampilan teknis yaitu kemampuan dalam menggunakan alatalat selama melakukan prosedur tindakan keperawatan. Dan ada juga keterampilan intelektual dimana keterampilan ini adalah keterampilan dalam memecahkan masalah, berpikir kritis setiap saat, dan membuat keputusan yang tepat dengan cepat.

Dalam proses keperawatan perawat juga haru menggunakan keterampilan berpikir kritis dalam setiap tahap dalam proses keperawatan. Dalam proses keperawatan mengandung banyak elemen berpikir kritis yang memungkinkan perawat membuat penilaian dan melakukan tindakan berdasarkan nalar. Proses adalah serangkaian tahapan atau komponen yang mengarah pada pencapaian pada tujuan. Tiga karakteristik dalam proses yaitu tujuan, kreativitas dan organisasi dimana tujuan disini dimaksud adalah spesifik atau tujuan dari proses. Organisasi adalah satu rangkaian tahap atau komponen yang diperlukan untuk mecapai tujuan sedangkan kreativitas adalah perkembangan bersimanbungan dari proses itu sendiri. Proses keperawatan adalah dinamik yang berkelanjutan. Proses keperawatan memberi cetak biru untuk berpikir kritis sehingga perawat dapat mengindividualisasikan asuhan dan berespon terhadap kebutuhan klien dengan tepat waktu dan cara yang masuk akal untuk memperbaiki atau mempertahankan tingkt kesehatan klien

\section{PENUTUP}

\section{KESIMPULAN}

Proses keperawatan adalah suatu pendekatan untuk pemecahaan masalah yang memampukan perawat untuk mengatur dan memberikan asuhan keperawatan. Proses keperawatan juga diartikan sebagai pendekatan yang digunakan perawat dalam memberikan asuhan keperawatan, sehingga kebutuhan dasar klien dapat terpenuhi.

Adapun fungsi dari proses keparawatan meliputi: yang pertama Membantu individu agar tidak bergantung pada orang lain

Kemudian Mengajak individu untuk bisa berpartisipasi dalam bidaang kesehatan

,Membantu individu untuk memperoleh derajat kesehatan yang optimal.

Dan fungsi terakhir adalah Membantu individ u untuk mengembangkan 
potensidalam memelihara kesehatan secara teratur. Proses keperawatan juga mempunyai sifat-sifat yaitu dinamis, siklikal, interdependen, dan fleksibel.

Dalam proses keperawatan perawat juga harus menggunakan keterampilan berpikir kritis dalam setiap tahap dalam proses keperawatan. Dalam proses keperawatan mengandung banyak elemen berpikir kritis yang memungkinkan perawat membuat penilaian dan melakukantindakan berdasarkan nalar.

\section{SARAN}

Perawat harus mampu melaksanakan proses keperawatan dengan baik dan benar karena mutu pelayanan keperawatan itu sendiri ditentukan oleh perawat yang kompeten dalam bidangnya sehingga kualitas praktik keperawatan dapat ditingkatkan dan Dalam proses keperawatan mengandung banyak elemen berpikir kritis yang memungkinkan perawat membuat penilaian dan melakukantindakan berdasarkan nalar.

\section{DAFTAR PUSTAKA}

Anggraini, Yuli, Purwaningsih,\& Eka Misbahatul ( 2010). Analisis Faktor Penyebab Pelaksanaan

Pendokumentasian Asuhan

Keperawatan Berdasarkan Balance Scrocard. Jurnal Ners. 5(1): 93-106.

Dermawan, Deden, Skep,Ns. (2012). Proses Keperawatan : Penerapan Konsep Dan Kerangka Kerja. Yogyakarta : Gosyen Publishing.

Deswani. (2009). Proses Keperawatan dan Berpikir Kritis. Jakarta : Salemba Medika.

Haryanto. (2007). Konsep Dasar Keperawatan Dengan Peemetaan Konsep. Jakarta : Salemba Medika.

Lestari, Tria Rini Pujii. ( 2014). Pendidikan Keperawatan : Upaya menghasilkan Tenaga Perawat Berkualitas. Aspirasi. 5(1).

Lismidar,H.(1990).Proses

Keperawatan. Jakarta : Universitas Indonesi. 
Marpaung, S. H. S. (2019). Penerapan

Proses Keperawatan dalam Pemenuhan

Personal Hygiene pada Pasien. osf.io.

Maryan,S, Santun ,S. (2007). Buku Ajar

Berpikir Kritis Dalam Proses

Keperawatan. Jakarta : EGC.

Potter \& Perry. (2005). Buku Ajar

Fundamental Keperawatan Konsep

Proses Dan Praktik Edisi 4. Jakarta :

EGC.

Potter \& Perry. ( 2010). Fundamental

Of Nursing : Edisi 7. Jakaarta : EGC.

Rohman, Nikmatur \& Saiful W. (2013).

Proses Keperawatan : Teori Dan

Aplikasi. Yogyakarta. AR-Ruzz Media

Roper, Nancy. (1996). Prinsip-Prinsip

Keperawatan. Yogyakarta : Andi

Yayasan Essentia Medica.

Setiadi. ( 2012). Konsep Dan Penulisan

Dokumentasi Asuhan Keperawatan. Jakarta : Salemba Medika.

Simamora, R. H. (2019). Menjadi Perawat yang : CIH'HUY. Surakarta.

Kekata Publisher.
Sumijatun.(2009). Manajemen

Keperawatn Konsep Dasar Dan Aplikasi Pengambilaan Keputusan Klinis. Jakarta : TIM.

Tarwoto \& Wartonah. (2012). Kebutuhan Dasar Manusia Dan Proses Keperawatan. Jakarta : Salemba Medika.

Terry, Cynthia. 2011. Keperawatan Kritis. Yogyakarta : Rapha Publishing. 